\title{
Determinants of Return to Work in Patients with Hand Disorders and Hand Injuries
}

\author{
Lonneke Opsteegh • Heleen A. Reinders-Messelink • \\ Donna Schollier · Johan W. Groothoff · Klaas Postema • \\ Pieter U. Dijkstra · Corry K. van der Sluis
}

Published online: 13 May 2009

(c) The Author(s) 2009. This article is published with open access at Springerlink.com

\begin{abstract}
Introduction Return to work (RTW) in patients with hand disorders and hand injuries is determined by several determinants not directly related to the physical situation. Besides biomedical determinants, work-related and psychosocial determinants may influence RTW as well. This study is conducted to investigate the influence of these potential determinants on RTW in patients with hand disorders and hand injuries. Methods Included 91 patients who were operatively treated for a hand disorder or a hand injury, and who were employed prior to surgery. Patients answered several questionnaires on the aforementioned categories. Potential determinants significantly related to
\end{abstract}

L. Opsteegh $(\bowtie) \cdot$ H. A. Reinders-Messelink $\cdot$ K. Postema

P. U. Dijkstra - C. K. van der Sluis

Centre for Rehabilitation, University Medical Center Groningen,

University of Groningen, P.O. Box 30.001, 9700 RB Groningen,

The Netherlands

e-mail: 1.opsteegh@cvr.umcg.nl

L. Opsteegh · J. W. Groothoff · K. Postema .

P. U. Dijkstra - C. K. van der Sluis

Department of Health Sciences, Graduate School for Health

Research, University Medical Center Groningen,

University of Groningen, Groningen, The Netherlands

H. A. Reinders-Messelink

Centre for Rehabilitation 'Revalidatie Friesland', Beetsterzwaag,

The Netherlands

D. Schollier

Center for Human Movement Sciences, University

of Groningen, Groningen, The Netherlands

P. U. Dijkstra

Department of Oral and Maxillofacial Surgery,

University Medical Center Groningen, University of Groningen,

Groningen, The Netherlands
RTW in a univariate analysis were entered in a logistic regression for the total group and the acutely injured patients separately. Results Pain, accident location, job independence and symptoms of post-traumatic stress disorder (PTSD) were univariately associated with RTW. Pain was a determinant for late RTW in the total group and accident location and symptoms of PTSD in the acutely injured group. Conclusion Pain, accident location and symptoms of PTSD were most important in resuming work in hand injured patients or in patients with a hand disorder. These findings may indicate that attention should be paid to the treatment of pain, and to the development of symptoms of PTSD during rehabilitation. It may be necessary to make extra efforts aimed at RTW in patients who sustained their injury on the job.

Keywords Employment - Hand injuries · Hand disorders · Posttraumatic stress disorder - Pain . Accident location

\section{Introduction}

Hand disorders and hand injuries negatively influence functional use of the hand, and may cause long periods of sick leave [1-6]. In general as duration of sick leave increases, the chance of return to work (RTW) decreases $[7,8]$. Barriers in returning to work often arise from personal, work or family-related problems, rather than from the original health condition itself [7]. Besides the physical or biomedical consequences of hand disorders and injuries contributing to duration of sick leave, other potential determinants such as work-related and psychosocial determinants contribute to duration of sick leave $[1-3,5,6$, 9-11]. 
In general, severe injuries seem to delay RTW more than minor injuries [6,12-14], although in patients with symptoms of PTSD this relationship could not be confirmed [5]. Furthermore, the negative influence of injury severity decreases when patients are motivated and psychologically stable [15]. Pain negatively influences RTW in hand injured patients $[4,6,11]$, although disagreement on this subject exists $[2,15]$.

Blue collar workers with hand injuries take longer to RTW than white collar workers do [2, 6, 9]. Whether the patient is self-employed or an employee influences RTW as well [6]. It is hypothesized that, as self-employed patients do not receive disability benefits from the state, they might be more financially dependent on their work, and therefore more motivated to resume their work [16]. The influence of company size, contact with work and other work-related characteristics is not clear $[6,8$, 16-18].

Several psychosocial determinants are related to RTW. Disturbed aesthetics or appearance of the hand can delay RTW [15, 19]. Negative reactions to the sight of the hand are suggested to be associated with both trauma-related distress and mood disorders in the early stage of an acute traumatic hand injury, which in turn may delay RTW [20]. Causal attributions contribute to the development of worksite avoidance, since workers who blame co-workers or equipment for their injuries are more likely to resist returning to former work activities than workers who judge themselves responsible for their accident [5, 19], thereby influencing RTW.

Post-traumatic stress disorder (PTSD) [21] in handinjured populations, characterized by nightmares, avoidance of the work-setting and (the type of) flashbacks, influences RTW negatively [19, 22-24].

Self-efficacy may be related to RTW also, but studies show inconsistent results. A difference may exist between task-specific and general self-efficacy [16, 25, 26]. High task-specific self-efficacy beliefs were related to successful work-role functioning at 6 months after carpal tunnel release [16]. Another important factor in adaptation to acute stress is a persons coping strategy. It has been suggested that active coping in the acute phase after an accident may be related to the development of PTSD, but it is protective in the later course of the rehabilitation [27]. However, no clear answer has been given on the influence of coping style on RTW.

Research suggests that an external health locus of control is related to adverse health behaviour, such as smoking and excessive drinking, in a rural community population [28]. An internal locus of control is related to a better psychological health, a more active involvement in social activities and a higher level of expressed satisfaction in a hand-injured population [29].
Finally, social support may contribute in a positive way to RTW at a later stage of recovery [16]. Practical social support was positively related to RTW in patients with fractures to the lower extremities [30].

As seen above, many potential determinants seem to have inconsistent and even contradictory relationships to RTW. The RTW process seems to be multifactorial determined and therefore multivariable models are needed to study this process [18]. Most studies however only analyse their data univariately, or include determinants from one or two categories [1-5, 8, 31]. Rarely potential determinants from all categories are studied simultaneously in patients with hand disorders or hand injuries [6]. Therefore, we aim at evaluating the influence of biomedical, psychosocial and work-related potential determinants on return to work in patients with a hand disorder or a hand injury.

\section{Methods}

Patients between 18 and 65 years of age with an operatively treated hand disorder or hand injury were included between April 2006 and March 2007. Patients were treated by a hand therapist at the Centre for Rehabilitation (CfR) of the University Medical Center Groningen or at the Centre for Rehabilitation 'Revalidatie Friesland' (RF), Leeuwarden, The Netherlands. Patients had to be employed, and capable of reading and understanding Dutch to be able to participate in the study. Patients with burn injuries, rheumatoid arthritis or other severe co-morbidities with expected extensive influence on RTW were excluded from the study. The study proposal was evaluated by the Medical Ethics Committee of the University Medical Center Groningen (UMCG). A formal ethics review was not required, because regular health care was evaluated and the research only posed a minor burden to the participants.

\section{Procedure}

After signing the informed consent form, patients were interviewed and were asked to fill out several questionnaires (see section "Measurements"). Patients reported their date of RTW via a return-form or were phoned in case no return-form was received (after 6 months). Patients who had not returned to work after 6 months were contacted again 2 years post-injury for information about their RTW.

\section{Measurements}

The primary outcome measure was return to work (RTW), defined as the period between date off work and date of resuming work. In patients with hand disorders, the date of surgery was chosen as a starting point for the period off 
work, while in patients with traumatic injuries, the date of injury was chosen as a starting point. Patients were categorized into early RTW when they resumed their job earlier than or equal to 10 weeks (E-RTW), or as late RTW when they took longer than 10 weeks to RTW (L-RTW).

Patients were asked at what time they returned to work (former or other job) at the same level as in the pre-surgery situation or at a stable level of working for at least $12 \mathrm{~h}$ a week. Patients were asked whether their job tasks changed after the injury, and whether they worked with the same colleagues as before.

Potential determinants contributing to RTW were identified in literature and subsequently, measurement instruments assessing these potential determinants were chosen (Table 1). A summary of the measurement instruments and psychometric properties is given in Appendix.

Table 1 Potential determinants and measurement instruments

\begin{tabular}{ll}
\hline Biomedical determinants & \\
Injury severity & HISS \\
Hand injured (dominance) & Medical chart/interview \\
Pain & MHOQ \\
Accident location & a \\
Cause of the injury (acute or non-acute) & Medical chart/interview \\
Psychosocial determinants & \\
Aesthetics of the hand & MHOQ \\
Satisfaction with the hand & MHOQ \\
Causal attributions & \\
PTSD & Interview \\
Self-efficacy & SRS-PTSD \\
Health locus of control & GSES \\
Coping style & MHLCS \\
Problem-solving style & UCL \\
Social support & SPSI-R \\
Work-related determinants & SSL \\
Sector & \\
Employment & Interview \\
Job independence & Interview \\
Participation & QEAW \\
Uncertainty about future & QEAW \\
Pleasure & QEAW \\
Involvement & QEAW \\
Size of the company & QEAW \\
Contact with employer & QRWD \\
\hline
\end{tabular}

HISS hand injury severity scoring system, MHOQ Michigan hand outcome questionnaire, $Q E A W$ questionnaire on the experience and assessment of work, $Q R W D$ questionnaire reintegration after work disability, SRS-PTSD self-rating scale for post-traumatic stress disorder, GSES general self-efficacy scale, MHLCS multidimensional health locus of control scale, UCL Utrecht coping list, SPSI-R social problem solving inventory-revised, $S S L$ social support list

a Submitted only to patients with acute hand injuries
The Questionnaire Reintegration after Work Disability (QRWD) [32] was used to add questions concerning sociodemographic determinants such as age, gender, marital status, educational level. As only small groups were formed using the 4 Hand Injury Severity Score (HISS)categories, HISS categories were dichotomized into minor/ moderate injuries and severe/major injuries; thereby creating groups of sufficient size for further analyses.

The Self-Rating Scale for PTSD measures symptoms of PTSD. To diagnose PTSD, patients should show at least one symptom of re-experiencing, three symptoms of avoidance, and two symptoms of hyperarousal. During a semi-structured interview questions were asked about the accident location, causal attributions, and job-specific information, such as job type (sector) and employment (self-employed or employee). The interview was recorded with an audiotape-recorder.

\section{Statistical Analyses}

Data were visually inspected with the help of diagrams and plots; subsequently, potential determinants with an interval data-level were tested for normality using KolmogorovSmirnov tests. To investigate associations between RTW and the various potential determinants, Mann-Whitney U tests, Kruskal-Wallis tests and Spearman correlations were performed for dichotomous determinants, categorical determinants, and for interval determinants respectively.

Differences between the two groups (E-RTW and LRTW) were analysed using the Mann-Whitney U test because of skewed distribution of interval determinants, and using Chi square-tests for categorical determinants.

Determinants univariately related to RTW were entered in the logistic regression analysis (Forward stepwise, likelihood ratio method). This analysis was performed for the total group of patients (excluding accident location and symptoms of PTSD), and for patients with an acute hand injury separately (including accident location and symptoms of PTSD). Associations and results concerning symptoms of PTSD, HISS, accident location and causal attributions were analysed for patients with acute hand injuries only.

\section{Results}

Analyses were performed on 91 (86\%) of the eligible 106 patients. Seven patients refused to participate because of time constraints, and one patient did not want to cooperate because of poor experiences with the local hospital. Seven had to be excluded because of substantial missing data, and one patient refused further cooperation, without reason given. 


\section{Return to Work}

Forty-four patients returned early to work (48\%, ERTW), and 47 patients did not return early to work (52\%, L-RTW) (Fig. 1). Of these 47 patients, eight patients took longer than one year to RTW (8/91; 9\%). Four of them did not resume their jobs within 2 years post-injury $(4 / 91 ; 4 \%)$. The median time to RTW was 10.5 weeks (Interquartile Range: 23 to 134). A total of 75 patients reported no changes on the job, five reported a change, and 11 did not answer the question or did not return the return-form. Of the five patients who reported a change, three noted explicitly that this change was not because of the hand injury. No significant differences in duration of sick leave between patients at the CfR and RF were found.

\section{Descriptives and Associations}

Sixty-nine persentage of the participants were male $(n=63)$. The mean age of the population was 43 years (SD 11.5). Most of the participants (76\%) were married or lived together with a partner, while $24 \%$ lived alone. Onethird of the patients had lower educational level (34\%), $43 \%$ of the patients had intermediate educational level, and $23 \%$ of the patients had a high level of education. Fortynine patients were treated at the RF and 42 were treated at the CfR.

\section{Biomedical Determinants}

Level of pain was significantly higher in the L-RTW group compared to the E-RTW group (Table 2). Accident location was dichotomised into "injury sustained on the job" and "injury sustained elsewhere", because of insufficient counts to perform Chi-squared tests. More patients in the L-RTW group sustained their injury on the job (77\%), than those in the E-RTW group $(38 \%)(P<.01)$. More patients in the L-RTW had sustained severe or major trauma compared to those of the E-RTW group, however, this difference was not significant (ns). Diagnoses are described in Table 2.

\section{Work-Related Determinants}

Job independence was significantly higher (lower scores) in the E-RTW group compared to the L-RTW (Table 3). More blue collar workers were present in the L-RTW group compared to the L-RTW (ns).

\section{Psychosocial Determinants}

Symptoms of PTSD scores were significantly higher in the L-RTW group compared to the E-RTW group (Table 4). However, scores on the Self-rating scale for post-traumatic stress disorder were low in almost all cases; only one of the patients was diagnosed with PTSD. Twenty-one patients
Fig. 1 Return to work (in weeks). The vertical dotted line shows the cut-off point for dichotomisation between early and late return to work (at 10 weeks)

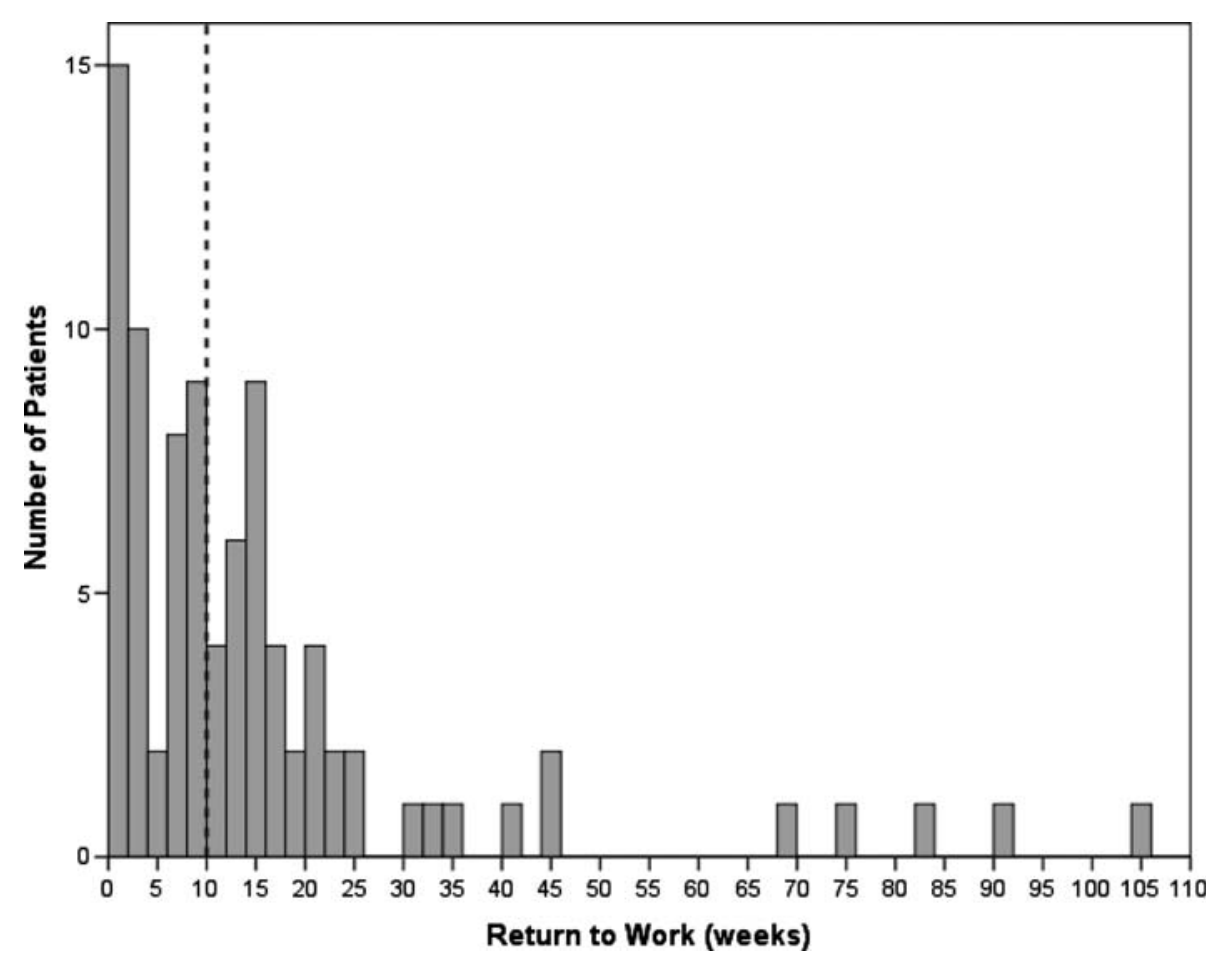


Table 2 Descriptives of biomedical determinants
$E-R T W$ early return to work, $L-$ $R T W$ late return to work, $I Q R$ interquartile range, HISS hand injury severity score, $M H O Q$ Michigan hand outcomes questionnaire

a Analysed for patients with acute injuries

* Chi-square test: $P<0.05$; ** Mann-Whitney U test: $P<0.05$. Differences in numbers of patients exist due to missing values

\begin{tabular}{|c|c|c|c|}
\hline & $\begin{array}{l}\text { Total group } \\
n\end{array}$ & $\begin{array}{l}\text { E-RTW } \\
(\mathrm{RTW} \leq 10 \text { weeks }) \\
n(\%)\end{array}$ & $\begin{array}{l}\text { L-RTW } \\
(\text { RTW > } 10 \text { weeks }) \\
n(\%)\end{array}$ \\
\hline \multicolumn{4}{|l|}{ Injury severity $^{\mathrm{a}}$ (HISS) } \\
\hline Minor/moderate & 37 & $20(54)$ & $17(46)$ \\
\hline Severe/major & 28 & $9(32)$ & $19(68)$ \\
\hline \multicolumn{4}{|l|}{ Cause of disorder } \\
\hline Acute injury & 68 & $30(44)$ & $38(56)$ \\
\hline Other disorder & 22 & $13(59)$ & $9(41)$ \\
\hline \multicolumn{4}{|l|}{ Affected hand } \\
\hline Dominant hand & 37 & $18(49)$ & $19(51)$ \\
\hline Non-dominant hand & 41 & $19(46)$ & $22(54)$ \\
\hline \multicolumn{4}{|l|}{ Accident location $^{\mathrm{a}}$} \\
\hline Injury sustained on the job & 30 & $7(23)$ & $23(77)^{*}$ \\
\hline Injury sustained elsewhere & 37 & $23(62)$ & $14(38)$ \\
\hline \multicolumn{4}{|l|}{ Diagnosis } \\
\hline Amputations & 5 & $2(40)$ & $3(60)$ \\
\hline Fractures & 18 & $10(56)$ & $8(44)$ \\
\hline Tendon injury & 13 & $3(23)$ & $10(77)$ \\
\hline Complex injury & 24 & $12(50)$ & $12(50)$ \\
\hline Morbus Dupuytren & 5 & $5(100)$ & $0(0)$ \\
\hline (Non) specific pain complaints & 12 & $6(50)$ & $6(50)$ \\
\hline Other & 14 & $6(43)$ & $8(57)$ \\
\hline Pain (median; IQR) (MHOQ) & $35(15-50)$ & $30(10-45)$ & $45(20-61)^{* *}$ \\
\hline
\end{tabular}

(33\%) scored no symptoms of PTSD; 12 patients (19\%) scored one symptom; the other patients scored two or more symptoms. More patients in the L-RTW group attributed there accident to machinery compared to the E-RTW group (ns).

\section{Regression Analysis}

Pain was associated with L-RTW in the total group of patients and symptoms of PTSD and accident location were associated with L-RTW in the acutely injured group (Table 5).

\section{Discussion}

Pain was found to be the major independent predictor for RTW in the total population, while accident location and symptoms of PTSD were found to be the independent predictors for RTW in patients with acute hand injuries. Pain (biomedical), accident location (biomedical), job independence (work-related), and symptoms of PTSD (psychosocial) influenced RTW in univariate analyses.
Half of the patients resumed their job within 10 weeks, while four patients took more than 2 years to RTW. These four patients have the right to claim disability benefits according to the Work Disability Act in The Netherlands. Possibly, these patients experience benefits from not resuming their work.

The 10 week cut-off point was chosen because in medical treatment protocols generally the affected hand may be fully used after this period. This 10 week period consists of 6 weeks to heal the injured tissues, and 4 weeks to re-strengthen the hand, and rebuild condition.

The negative impact of pain on RTW has been established in several studies on hand injured patients $[4,6,9$, $11,33]$. Pain was earlier found to be a stress factor in the early stage of acute traumatic hand injuries [33] and after one year the amount of pain was negatively related to RTW [9]. When patients experience more pain, they may tend to become more cautious in using their hands, and therefore wait longer to RTW. Nevertheless, in the current study pain had impact on RTW in all patients with hand injuries and hand disorders. This finding imposes the need to pay longlasting attention to pain in all patients with hand disorders and acute injuries, thereby taking into account the type of pain (non-specific or specific) and adjusting treatment accordingly. 
Table 3 Descriptives of workrelated determinants
$I Q R$ interquartile range, $E-R T W$ early return to work, $L-R T W$ late return to work, $Q E A W$ questionnaire on the experience and assessment of work, $Q R W D$ questionnaire reintegration after work disability

* Mann-Whitney U test: $P<0.05$. Differences in numbers of patients exist due to missing values

\begin{tabular}{|c|c|c|c|c|}
\hline & $\begin{array}{l}\text { Total } \\
\text { group } \\
n\end{array}$ & \multicolumn{2}{|c|}{$\begin{array}{l}\text { E-RTW } \\
(\mathrm{RTW} \leq 10 \text { weeks }) \\
n(\%)\end{array}$} & $\begin{array}{l}\text { L-RTW } \\
(\text { RTW > } 10 \text { weeks }) \\
n(\%)\end{array}$ \\
\hline \multicolumn{5}{|l|}{ Sector } \\
\hline Blue collar worker & 60 & \multicolumn{2}{|c|}{$23(38)$} & $37(62)$ \\
\hline White collar worker & 23 & \multicolumn{2}{|c|}{$14(61)$} & $9(39)$ \\
\hline \multicolumn{5}{|l|}{ Employment } \\
\hline Self-employed & 15 & \multicolumn{2}{|c|}{$9(60)$} & $6(40)$ \\
\hline Employee & 73 & \multicolumn{2}{|c|}{$33(45)$} & $40(55)$ \\
\hline \multicolumn{5}{|l|}{ Contact with work (QRWD) } \\
\hline Yes & 63 & \multicolumn{2}{|c|}{$26(41)$} & $37(59)$ \\
\hline No & 17 & \multicolumn{2}{|c|}{$11(65)$} & $6(35)$ \\
\hline No sick leave & 2 & \multicolumn{2}{|l|}{2} & 0 \\
\hline No employer & 5 & \multicolumn{2}{|l|}{4} & 1 \\
\hline \multicolumn{5}{|l|}{ Size of the company (QRWD) } \\
\hline$<100$ & 51 & \multicolumn{2}{|c|}{$22(43)$} & $29(57)$ \\
\hline $100-500$ & 19 & \multicolumn{2}{|c|}{$12(63)$} & $7(37)$ \\
\hline$>500$ & 14 & \multicolumn{2}{|c|}{$6(43)$} & $8(57)$ \\
\hline $\begin{array}{l}\text { Unknown by } \\
\text { employee }\end{array}$ & 1 & \multicolumn{2}{|c|}{$1(100)$} & \\
\hline Work-characteristics (QEAW) & \multicolumn{2}{|c|}{ Median (IQR) } & Median (IQR) & Median (IQR) \\
\hline Job independence & \multicolumn{2}{|c|}{$39.4(16.7-54.5)$} & $33.3(18.2-48.5)$ & $51.5(24.2-58.3)^{*}$ \\
\hline Participation & \multicolumn{2}{|c|}{$41.7(29.2-56.2)$} & $43.8(30.2-57.3)$ & $37.5(27.1-54.2)$ \\
\hline Uncertainty about the future & \multicolumn{2}{|c|}{$16.7(0.0-47.9)$} & $16.7(0-41.7)$ & $16.7(0-50.0)$ \\
\hline Pleasure in work & \multicolumn{2}{|c|}{$11.1(3.7-26.9)$} & $13.0(3.7-30.6)$ & $11.1(3.7-22.2)$ \\
\hline Involvement in the organisation & \multicolumn{2}{|c|}{$12.5(12.5-37.5)$} & $12.5(12.5-37.5)$ & $25.0(12.5-37.5)$ \\
\hline
\end{tabular}

Accident location, when dichotomized, appeared to be a determinant of RTW: patients who sustained their injury on the job were almost eight times more likely to take longer than 10 weeks to RTW. From one study it is known that workers who blame co-workers or equipment for their injuries are more likely to resist returning to former work activities [5]. Although many studies on RTW include patients with job-related injuries $[5,6,10,18,24,29$, 34-38], the association between RTW and accident location has not been studied extensively. Our results suggest that extra efforts should be aimed at RTW in patients who sustained their injury on the job.

Job independence was univariately associated with RTW, but did not contribute to the regression equation. In literature the relation between sick leave and job independence/decision latitude has been suggested repeatedly [10, 18, 39]; more job independence would fasten RTW. However, substantial evidence for this suggestion is, to the best of our knowledge, lacking. In the current study, the direction of the relation was as expected: more independence in the job is related to E-RTW.

In the current study symptoms of PTSD were a determinant of L-RTW in patients with acute hand injuries.
Although patients showed only few symptoms of PTSD, these symptoms delayed RTW significantly. PTSD is characterized by avoidance, hyperarousal and re-experiencing of the traumatic event [21]. It is frequently diagnosed in patients with acute hand injuries [19, 22-24]. In the current study a great amount of injuries were sustained during work (45\%). Therefore, it was expected that symptoms of avoidance would impact RTW [15, 24]. Flashbacks, a specific form of re-experiencing the trauma, are known to delay RTW significantly. Additionally, when patients return to the place of the original injury the amount and severity of flashback can increase dramatically $[6,24]$. In the current study the three components of PTSD were not analysed separately, as the total score was used as an indicator of PTSD to limit the number of potential determinants. However, future research analysing effects of components of PTSD on RTW could provide more insight.

The current study underscores the importance of paying attention to symptoms of PTSD at an early stage in rehabilitation treatment. Currently, only when clear indications for PTSD exist, a psychologist gets involved in the treatment. However, since even a limited number of symptoms 
Table 4 Descriptives of psychosocial determinants

\begin{tabular}{|c|c|c|c|}
\hline & $\begin{array}{l}\text { Total group } \\
n \text { or median (IQR) }\end{array}$ & $\begin{array}{l}\text { E-RTW } \\
(\mathrm{RTW} \leq 10 \text { weeks }) \\
n(\%)\end{array}$ & $\begin{array}{l}\text { L-RTW } \\
(\mathrm{RTW}>10 \text { weeks }) \\
n(\%)\end{array}$ \\
\hline \multicolumn{4}{|l|}{ Causal attributions ${ }^{\mathrm{a}}$} \\
\hline Internal & 10 & $5(50)$ & $5(50)$ \\
\hline Other person & 2 & $1(50)$ & $1(50)$ \\
\hline Machinery & 25 & $8(32)$ & $17(68)$ \\
\hline Other & 19 & $8(42$ & $11(58)$ \\
\hline Aesthetics of the hand (MHOQ) & $60.0(45.0-70.0)$ & $60(45-70)$ & $55(45-70)$ \\
\hline Satisfaction with the hand (MHOQ) & $62.5(41.7-77.1)$ & $66(46-79)$ & $52(41-75)$ \\
\hline Symptoms of PTSD ${ }^{\mathrm{a}}$ & $1(0-4)$ & $0(0-2)$ & $3(1-5)^{*}$ \\
\hline Self-efficacy (GSES) & $48.0(42.0-58.0)$ & $48.5(42.3-54.8)$ & $48(42-61)$ \\
\hline \multicolumn{4}{|l|}{ Health locus of Control (MHLCS) } \\
\hline Internal & $19.0(16.0-21.5)$ & $19(16-21)$ & $19(16-22)$ \\
\hline Chance & $23.0(19.0-27.0)$ & $24(21-28)$ & $22(19-26)$ \\
\hline Doctors & $26.0(23.0-30.0)$ & $27(23-29)$ & $26(22-30)$ \\
\hline \multicolumn{4}{|l|}{ Coping (UCL) } \\
\hline Active coping & $16(14-18)$ & $16(13-18)$ & $16(14-18)$ \\
\hline Palliative reaction & $16(15-18)$ & $16(15-18)$ & $16(15-19)$ \\
\hline Avoidance style & $16(13-17)$ & $16(12-16)$ & $15(13-18)$ \\
\hline Social support seeking & $13(11-15)$ & $12(11-15)$ & $13(10-15)$ \\
\hline Passive reaction & $10(9-12)$ & $10(8-12)$ & $10(9-12)$ \\
\hline Expression of emotions & $6(5-7)$ & $6(5-7)$ & $6(5-7)$ \\
\hline Reassuring thoughts & $12(11-14)$ & $12(11-14)$ & $13(11-14)$ \\
\hline \multicolumn{4}{|l|}{ Problem-Solving (SPSI-R) } \\
\hline Negative problem orientation & $8.0(4.0-15.0)$ & $9(4-15)$ & $7(4-15)$ \\
\hline Positive problem orientation & $12.0(9.0-15.0)$ & $12(9-14)$ & $12(9-16)$ \\
\hline Rational problem solving & $41.0(33.0-52.5)$ & $41(32-53)$ & $43(36-51)$ \\
\hline Impulsive careless style & $12.0(9.0-15.3)$ & $12(9-16)$ & $11(9-15)$ \\
\hline Avoidance style & $7.0(4.0-10.5)$ & $7.5(3.8-11.0)$ & $7(4-10)$ \\
\hline \multicolumn{4}{|l|}{ Social Support (SSL) } \\
\hline Everyday support & $11.0(9.0-12.0)$ & $11(9-12)$ & $11(9-12)$ \\
\hline Support in problem situations & $10.0(8.0-12.0)$ & $10(8-12)$ & $10(8-12)$ \\
\hline Esteem support & $11.0(9.0-12.0)$ & $10.5(8.8-12.0)$ & $11(9-12)$ \\
\hline
\end{tabular}

$I Q R$ interquartile range, $E-R T W$ early return to work, $L-R T W$ late return to work, $M H O Q$ Michigan hand outcomes questionnaire, $P T S D$ post traumatic stress disorder, GSES general self-efficacy scale, MHLCS multidimensional health locus of control scale, UCL Utrecht coping scale, $S P S I-R$ social problem solving inventory, SSL social support list interactions

${ }^{a}$ Analysed for patients with acute injuries

* Mann-Whitney U test: $P<0.001$. Differences in numbers of patients exist due to missing values

of PTSD influence RTW, psychological help should be offered in the treatment of acute hand-injured patients at all times.

Striking in the current study was that only a few determinants were related to RTW, although the potential determinants, biomedical, work-related and psychosocial, assessed in this study were carefully selected on the basis of an extensive literature study concerning hand-injured populations and general populations. When inspecting our results, some trends were noticed. Firstly, most patients with major or severe injuries (68\%) were categorized as L-RTW, while patients with minor or moderate injuries were more evenly distributed over the E-RTW and L-RTW categories. Only major or severe hand injuries seem to delay RTW. Being a blue collar worker also seemed to delay RTW. As blue collar jobs are often more physically demanding, hand 
Table 5 Logistic regression analysis to predict L-RTW

\begin{tabular}{lcll}
\hline Independents & Beta & S.E. & $\operatorname{Exp}(\mathrm{B})$ \\
\hline Total group $(N=84)$ & & & \\
$\quad$ Constant & -0.715 & 0.392 & 0.489 \\
$\quad$ Pain (per point) & 0.022 & 0.01 & 1.022 \\
Acute injuries $(N=62)$ & & & \\
$\quad$ Constant & -1.528 & 0.0511 & 0.217 \\
$\quad$ S-PTSD (per point) & 0.337 & 0.123 & 1.401 \\
$\quad$ Accident location $(0=$ elsewhere; & 2.068 & 0.639 & 7.906 \\
$1=$ job) & & &
\end{tabular}

$L-R T W$ late return to work, S.E. standard error, $\operatorname{Exp}(B)$ odds, S-PTSD symptoms of posttraumatic stress disorder

injuries could be more debilitating in this sector than in white collar jobs.

In previous studies RTW in hand-injured patients ranged from 6.1 days [6] to 31.3 weeks [2]. One study reported a mean time off work in patients with digital nerve lesions of 9.5 weeks and in patients with non-digital nerve lesions of 21.4 weeks [4]. The great variability in RTW in literature can partly be explained by differences in study populations, and differences in defining RTW. Most studies are conducted on homogeneous populations, such as occupational injuries or nerve injuries [2-6, 23, 24, 29]. Additionally in most studies on RTW in hand injured patients only determinants from one or two categories were assessed $[1-3,5,11,15,19,20,22-24,29,33]$.

\section{Strengths and Weaknesses}

The strength of the current study is that we combine biomedical, work-related and psychosocial potential determinants. In reality, not only biomedical, work-related or psychosocial determinants influence RTW, but the combination of determinants from all categories may be crucial. Potential determinants in the current study were selected on the basis of literature review into hand-injured populations and general populations, leading to a selection of biomedical, work-related and psychosocial potential determinants. However, the relatively small sample size precludes drawing hard conclusions, which is a limitation of our study. A larger sample size would also create the possibility to study differential time effects in different subpopulations.
The main reason to refuse participation was time constraints. It may be that these patients resumed their jobs in an early stage, and therefore could not find time to participate in the study, resulting in an underestimation of the E-RTW group.

Additionally, a substantial amount of missing data was present in the results, which may have been caused by the large number of questionnaires. Patients may have become tired or bored filling out the questionnaires. Another issue that could have influenced the outcome of our study is that we used scales of some questionnaires instead of complete questionnaires. However, we only selected scales if the items within these scales were not mixed with items from other scales.

Time of RTW was measured with self-reported data inducing some information bias. It would have been better if these data were received directly from company records or insurance companies [40]. As probably both under- and overestimation occurs, it is conceivable that no systematic error is present in our RTW data.

\section{Future Research}

Pain, if uncontrolled and prolonged, may be an important stressor that could result in the development of PTSD [41]. Therefore, it is interesting to study the influence of pain on PTSD in acutely hand-injured patients. To investigate the influence of various potential determinants on RTW, it is a necessity to combine determinants from different categories, as some determinants may interact with each other. Further research should include a greater number of patients; thereby reaching sufficient sample size to investigate possible interactions. As displayed in Appendix, psychometric properties of many questionnaires have not been investigated fully, thus more research is needed in this area. Finally, different definitions of RTW are currently used in research; consensus should be reached about how to define RTW.

Open Access This article is distributed under the terms of the Creative Commons Attribution Noncommercial License which permits any noncommercial use, distribution, and reproduction in any medium, provided the original author(s) and source are credited.

\section{Appendix}

See Table 6. 


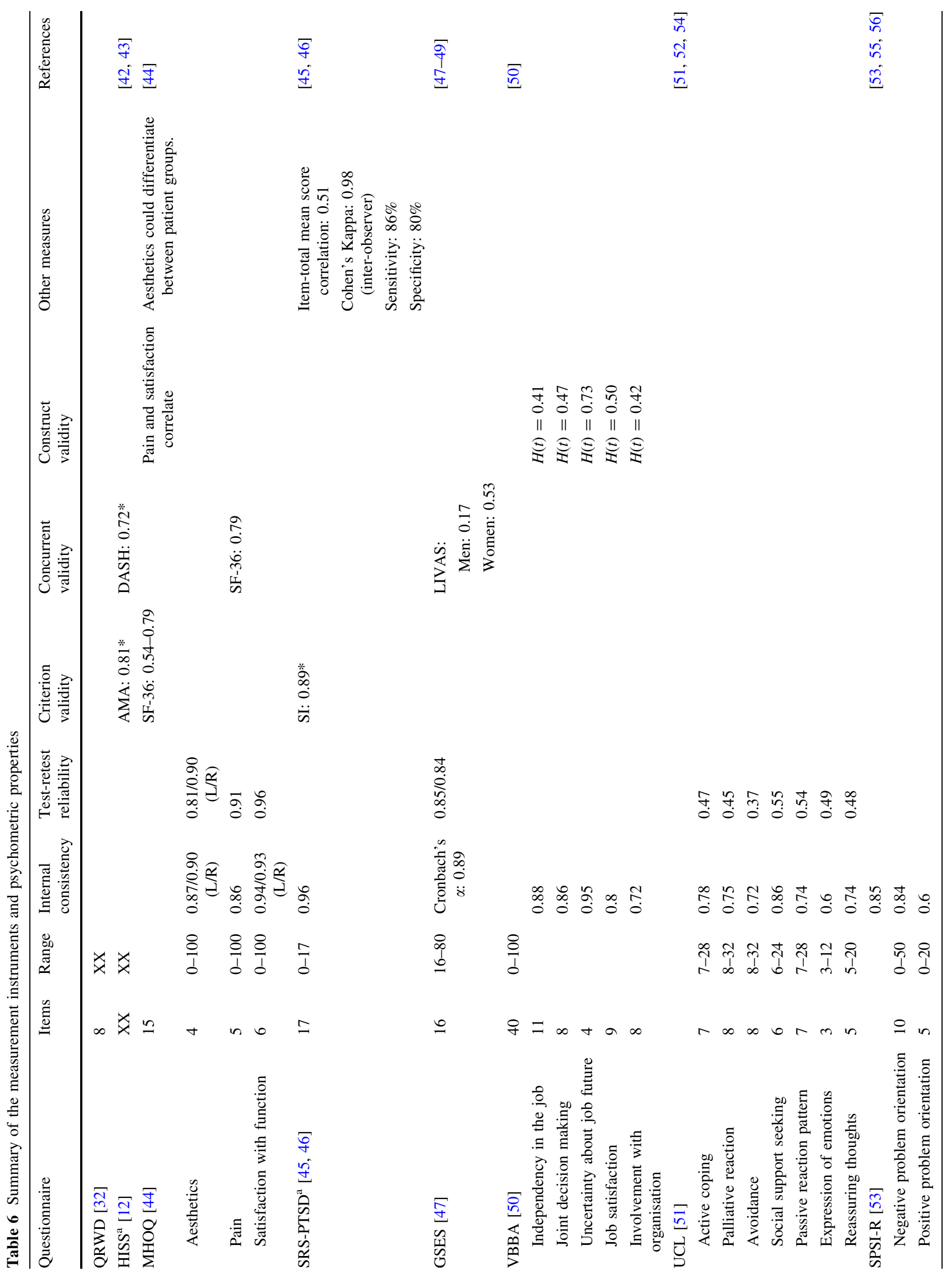




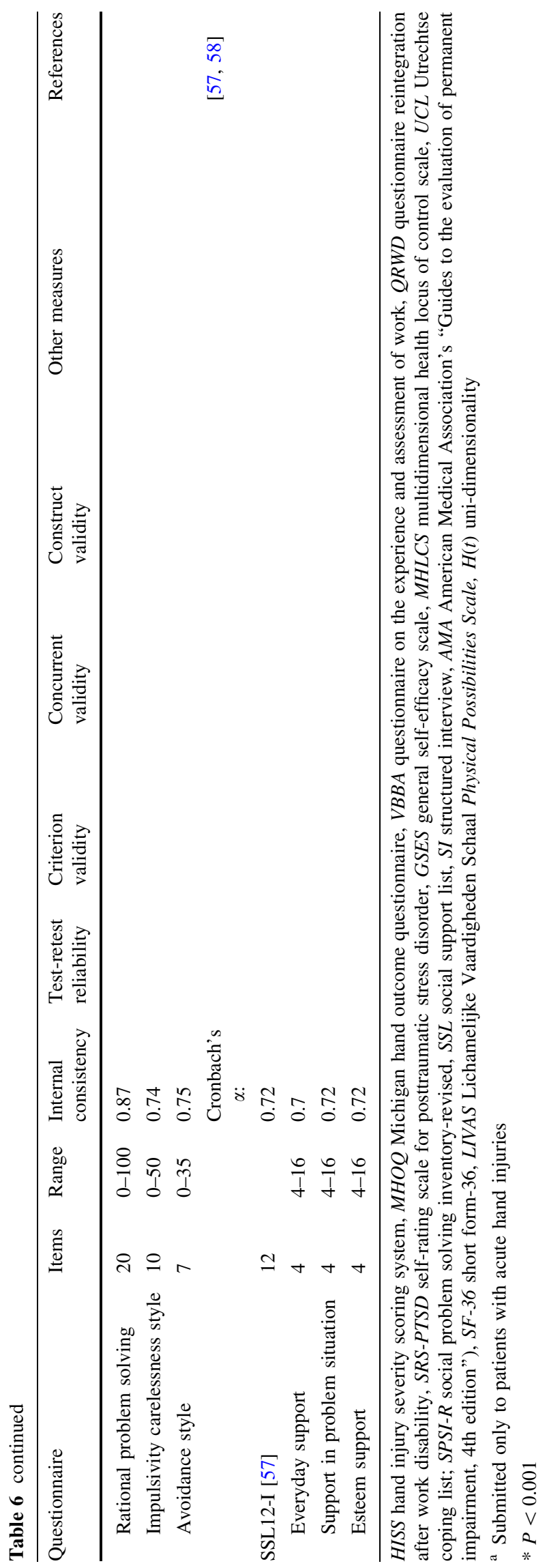

\section{References}

1. Bear-Lehman J. Factors affecting return to work after hand injury. Am J Occup Ther. 1983;27:189-94.

2. Bruyns CNP, Jaquet JB, Schreuders TAR, Kalmijn S, Kuypers PDL, Hovius SER. Predictors for return to work in patients with median and ulnar nerve injuries. J Hand Surg. 2003;28A:28-34. doi:10.1053/jhsu.2003.50026.

3. Kasdan ML, June LA. Returning to work after a unilateral hand fracture. J Occup Med. 1993;35:132-5. doi:10.1097/00043764199302000-00013.

4. Meiners PM, Coert JH, Robinson PH, Meek MF. Impairment and employment issues after nerve repair in the hand and forearm. Disabil Rehabil. 2005;27:617-23. doi:10.1080/09638280500030423.

5. Rusch MD, Dzwierzynski WW, Sanger JR, Pruit NT, Siewert AD. Return to work outcomes after work-related hand trauma: the role of causal attributions. J Hand Surg. 2003;28A:673-7. doi: 10.1016/S0363-5023(03)00178-3.

6. Skov O, Jeune B, Lauritsen JM, Barfred T. Time off work after occupational hand injuries. J Hand Surg. 1999;24B:187-9.

7. Health and Safety Executive [HSE] Guidance. Working together to prevent sickness absence becoming job loss-practical advice for safety and other trade union representatives. UK: Health and Safety Executive [HSE] Guidance; 2005.

8. Post M, Krol B, Groothoff JW. Work-related determinants of return to work in employees on long-term sickness absence. Disabil Rehabil. 2005;27:481-8. doi:10.1080/09638280400018601.

9. Gustafsson M, Ahlstrom G. Problems experienced during the first year of an acute traumatic hand injury - a prospective study. J Clin Nurs. 2004;13:986-95. doi:10.1111/j.1365-2702.2004.01019.x.

10. Krause N, Lund T. Returning to work after occupational injury. In: Barling J, Frone M, editors. The psychology of workplace safety. 1st ed. Washington, DC: American Psychological Association; 2004. p. 265-95.

11. Wahi Michener SK, Humphrey BA, Stepp DR, Moyers PA. Relationships among grip strength, functional outcomes, and work performance following hand trauma. Work. 2001;16:209-17.

12. Campbell DA, Kay SPJ. The hand injury severity scoring system. J Hand Surg. 1996;21B:295-8.

13. Mink van der Molen AB, Matloub HS, Dzwierzynski W, Sanger JR. The hand injury severity scoring system and workers' compensation cases in Wisconsin, USA. J Hand Surg. 1999;24B: 184-6.

14. Watts AMI, Greenstock M, Cole RP. Outcome following the rehabilitation of hand trauma patients. J Hand Surg. 1998;23B: 485-9.

15. Grob M, Papadopulos NA, Zimmermann A, Biemer E, Kovacs L. The psychological impact of severe hand injury. J Hand Surg. 2008;33E:358-62.

16. Amick BC, Habeck RV, Ossmann J, Fossel AH, Keller R, Katz JN. Predictors of successful work role functioning after carpal tunnel release surgery. J Occup Environ Med. 2004;46:490-500. doi:10.1097/ 01.jom.0000126029.07223.a0.

17. Janssen N, van den Heuvel WPM, Beurskens AJHM, Nijhuis FJN, Schröer CAP, van Eijk JTM. The demand-control-support model as predictors of return to work. Int J Rehabil Res. 2003;26: 1-9. doi:10.1097/00004356-200303000-00001.

18. Krause N, Frank JW, Dasinger LK, Sullivan TJ, Sinclair SJ. Determinants of duration of disability and return-to-work after work-related injury and illness: challenges for future research. Am J Ind Med. 2001;40:464-84. doi:10.1002/ajim.1116.

19. Grunert BK, Dzwierzynski WW. Prognostic factors for return to work following severe hand injuries. Tech Hand Up Extrem Surg. 1997;1:213-8.

20. Gustafsson M, Amilon A, Ahlstrom G. Trauma-related distress and mood disorders in the early stage of an acute traumatic hand injury. J Hand Surg. 2003;28B:332-8. 
21. American Psychiatric association. Diagnostic and statistical manual of mental disorders. 4th ed. Washington DC: American Psychiatric Association; 2000.

22. Grunert BK, Smith CJ, Fehring BA, Matloub HS, Sanger JR, Yousif NJ. Early psychological aspects of severe hand injury. J Hand Surg. 1988;13B:177-80.

23. Grunert BK, Devine CA, McCallum-Burke S, Matloub HS, Sanger JR, Yousif NJ. On-site work evaluations: desensitisation for avoidance reactions following severe hand injuries. J Hand Surg. 1989;14B:239-41.

24. Grunert BK, Devine CA, Matloub HS, Sanger JR, Yousif NJ, Anderson RC, et al. Psychological adjustment following workrelated hand injury: 18-month follow-up. Ann Plast Surg. 1992;29: 537-42.

25. Regenold M, Sherman MF. Getting back to work: self-efficacy as a predictor of employment outcome. Psychiatr Rehabil J. 1999; 22:361-7.

26. Labriola M, Lund T, Christensen KB, Albertsen K, Bültmann U, Jensen JN, et al. Does self-efficacy predict return-to-work after sickness absence? A prospective study among 930 employees with sickness absence for three weeks or more. Work. 2007;29:233-8.

27. Hepp U, Moergeli H, Büchi S, Wittmann L, Schnyder U. Coping with serious accidental injury: a one-year follow-up study. Psychother Psychosom. 2005;74:379-86. doi:10.1159/000087786.

28. Kuwahara A, Nishino Y, Ohkubo T, Tsuji I, Hisamichi S, Hosokawa T. Reliability and validity of the multidimensional health locus of control scale in Japan: relationship with demographic factors and health-related behavior. Tohoku J Exp Med. 2004;203:37-45. doi: 10.1620/tjem.203.37.

29. Lee PW, Ho ES, Tsang AK, Cheng JC, Leung PC, Cheng YH, et al. Psychosocial adjustment of victims of occupational hand injuries. Soc Sci Med. 1985;20:493-7. doi:10.1016/0277-9536 (85)90365-X.

30. MacKenzie EJ, Morris JA, Jurkovich GJ, Yasui Y, Cushing BM, Burgess AR, et al. Return to work following injury: the role of economic, social and job-related factors. Am J Public Health. 1998;88:1630-7. doi:10.2105/AJPH.88.11.1630.

31. Michaels AJ, Michaels CE, Moon CH, Zimmerman MA, Peterson C, Rodriguez JL. Psychosocial factors limit outcomes after trauma. J Trauma. 1998;44:644-8. doi:10.1097/00005373-199 804000-00013.

32. Nijboer ID, Gründemann RWM, Andries F.Werkhervatting na arbeidsongeschiktheid: onderzoek naar de kans op werkhervatting na een half tot anderhalf jaar na het einde van het ziektewetjaar en naar de kans van hervatters om aan het werk te komen bij de oude of een nieuwe werkgever. 's-Gravenhage, Ministerie van Sociale Zaken en Werkgelegenheid. 1993.

33. Gustafsson M, Persson LO, Amilon A. A qualitative study of stress factors in the early stage of an acute traumatic hand injury. $\mathrm{J} \mathrm{Adv}$ Nurs. 2000;32:1333-40. doi:10.1046/j.1365-2648.2000.01630.x.

34. Anderson RC, Grunert BK. A cognitive behavioral approach to the treatment of post-traumatic stress disorder after work-related trauma. Prof Saf. 1997;42:39-43.

35. Lombardi DA, Sorock GS, Lesch MF, Hauser R, Eisen EA, Herrick RF, et al. A reliability study of potential risk factors for acute traumatic occupational hand injuries. Am J Ind Med. 2002; 42:336-43. doi:10.1002/ajim.10120.

36. Asmundson GJCA, Norton GR, Allerdings MD, Norton PJ, Larsen DK. Posttraumatic stress disorder and work-related injury. J Anxiety Disord. 1998;12:57-70. doi:10.1016/S0887-6185(97) 00049-2.

37. MacDonald HA, Colotla V, Flamer S, Karlinsky H. Posttraumatic stress disorder (PTSD) in the workplace: a descriptive study of workers experiencing PTSD resulting from work injury. J Occup Rehabil. 2003;13:63-77. doi:10.1023/A:1022563930482.
38. Guzman J, Yassi A, Cooper JE, Khokhar J. Return to work after occupational injury. Can Fam Physician. 2002;48:1912-9.

39. Klein Hesselink DJ. Afwezigheid verklaard: literatuurstudie naar determinanten van ziekteverzuim en arbeidsongeschiktheid. Amsterdam: Nederlands Instituut voor Arbeidsomstandigheden (NIA); 1993.

40. van Poppel MNM, de Vet HCW, Koes BW, Smid T, Bouter LM. Measuring sick leave: a comparison of self-reported data on sick leave and data from company records. Occup Med. 2002;52:48590. doi:10.1093/occmed/52.8.485.

41. Schreiber S, Galai-Gat T. Clinical note: uncontrolled pain following physical injury as the core-trauma in post-traumatic stress disorder. Pain. 1993;54:107-10. doi:10.1016/0304-3959(93)90105-X.

42. Mink van der Molen AB, Ettema AM, Hovius SER. Outcome of hand trauma: the hand injury severity scoring system (HISS) and subsequent impairment and disability. J Hand Surg. 2003;28B: 295-9.

43. Saxena P, Cutler L, Feldberg L. Assessment of the severity of hand injuries using 'hand injury severity score', and its correlation with the functional outcome. Injury. 2004;35:511-6.

44. Chung KC, Pillsbury MS, Walters MR, Haywood RA. Reliability and validity testing of the Michigan hand outcomes questionnaire. J Hand Surg. 1998;23:575-87.

45. Carlier IVE, van Uchelen JJ, Lamberts RD, Gersons BPR. Een korte screeningstest voor de diagnose posttraumatische stressstoornis. Tijdschrift voor Psychiatrie. 1996;38:624-9.

46. Carlier IVE, Lamberts RD, van Uchelen AJ, Gersons BPR. Clinical utility of a brief diagnostic test for posttraumatic stress disorder. Psychosom Med. 1998;60:42-7.

47. Sherer M, Maddux JE, Mercadante B, Prentice-Dunn S, Jacobs B, Rogers RW. The self-efficacy scale: construction and validation. Psychol Rep. 1982;51:663-71.

48. Bosscher RJ, Smit JH, Kempen GIJM. Algemene compententieverwachtingen bij ouderen - een onderzoek naar de psychometrische kenmerken van de Algemene Competentieschaal (ALCOS). Nederlands Tijdschrift voor de Psychologie en Haar Grensgebieden. 1997;52:239-48.

49. Bosscher RJ, Smit JH. Confirmatory factor analysis of the general self-efficacy scale. Behav Res Ther. 1998;36:339-43. doi:10.1016/ S0005-7967(98)00025-4.

50. van Veldhoven M, Meijman TF, Broersen JPJ, Fortuin RJ. Handleiding VBBA. 2nd ed. Amsterdam: SKB Vragenlijstservices; 2002.

51. Schreurs PJG, van de Willige G, Brosschot JF, Tellegen B, Graus GMH. De Utrechtse Copinglijst (UCL): Omgaan met problemen en gebeurtenissen. Lisse: Swets \& Zeitlinger Test Services; 1993.

52. Sanderman R, Ormel J. De Utrechtse Copinglijst (UCL): validiteit en betrouwbaarheid. Gedrag en Gezondheid. 1992;20:32-7.

53. D'Zurilla TJ, Nezu AM, Maydeu-Olivares A. Social problem solving inventory-revised (SPSI-R): technical manual. North Tonawanda: Multihealth Systems; 2002.

54. Schaufeli W, van Dierendonck D. De betrouwbaarheid en validiteit van de Utrechtse Coping Lijst: een longitudinaal onderzoerzoek bij schoolverlaters. Gedrag en Gezondheid. 1992;20:38-45.

55. Sadowski C, Moore LA, Kelley ML. Psychometric properties of the social problem solving inventory (SPSI) with normal and emotionally disturbed adolescents. J Abnorm Child Psychol. 1994;22: 487-500. doi:10.1007/BF02168087.

56. Siu AMH, Shek DTL. The Chinese version of the social-problem solving inventory: some initial results on reliability and validity. $\mathrm{J}$ Clin Psychol. 2005;61:347-60. doi:10.1002/jclp.20023.

57. van Eijk LM, Kempen GIJM, van Sonderen FLP. Een korte schaal voor het meten van sociale steun bij ouderen: de SSL12-I. Tijdschr Gerontol Geriatr. 1994;25(19):2-198.

58. Kempen GIJM, van Eijk LM. The psychometric properties of the SS12-I, a short scale for measuring social support in the elderly. Soc Indic Res. 1995;35:303-13. doi:10.1007/BF01079163. 